6042

Research Note

Journal of Extension Education

Vol. 30 No. 1, 2018

DOI:https://doi.org/10.26725/JEE.2018.1.30.6042-6046

\title{
Technology Utilization Pattern of Cassava Growers on Recommended Cultivation Practices
}

\author{
A. Archana ${ }^{1}$, Rexlin Selvin ${ }^{2}$ and A. Muhammed Iqshanullah ${ }^{3}$
}

\begin{abstract}
A study was conducted to assess the Technology Utilization Pattern of cassava growers in Salem district of Tamil Nadu. Farmers were selected based on the area of cultivation of cassava. The technology utilization pattern of cassava growers revealed that they had medium to low level of knowledge about cassava cultivation practices.
\end{abstract}

Keywords : Technology utilization pattern; Crop improvement technology; Plant protection technologies; Tamil Nadu.

Cassava, popularly known as Tapioca, is one of the most important crop in poorer areas, because of its ability to grow well even under drought condition. Cassava supports food security and income for over 800 million people worldwide. ( Howeler et al. 2013).

India ranks tenth in the production of cassava cultivation. It is cultivated in many tropical states in India, as an industrial crop (Tamil Nadu and Andhra Pradesh), while in some states (Kerala and North Eastern states) it is being used as food crop. Cassava industry is an agro based seasonal industry with huge employment potential in India. It is mainly processed into starch and sago. There are more than 1000 cassava processing units in India producing starch and sago in cottage and small scale sectors.

In Tamil Nadu, cassava is a major horticulture crop and is ranked first both in its productivity (4344 MT) and processing like sago and starch (800 units approximately) industries. This is the major crop in the districts of Salem, Namakkal, Erode, Tiruvannamalai, Villupuram, Dharmapuri and Karur, and sustains more than three lakh farmers. A significant section of them are tribals. With this background, the study was conducted to measure the technology utilization pattern of cassava growers on the recommended cultivation practices.

Technology Utilization Pattern is the process of making full use of the recommended technologies by the clients. The prime duty of extension functionaries is not only to spread improved farm technologies to the farming community but also to make the innovations adopted by the farmers in order to ensure

1 PG Scholar, 2 Professor (Agrl. Extension) and 3. Ph.D Scholar, Dept. of Agricultural Extension and Rural Sociology, Madurai.

Received : 10-09-2018; Accepted : 25-10-2018 
higher productivity. Hence an attempt was made to assess the technology utilization pattern of cassava farmers under four sub heads crop improvement technologies, crop production technologies, crop protection technologies and harvest related technologies.

\section{METHODOLOGY}

Salem district was purposefully selected for its maximum area and production (83526 hectares and 2499280 tonnes) in the state of Tamil Nadu. About 80 per cent of country's needs of starch and sago are supplied from Salem and its neighboring districts. The district consists of twenty blocks. Among them three blocks were selected based on the highest area and cultivation (6719 ha) viz., Attur, Gangavalli and Pethanaickenpalayam.

\section{FINDINGS AND DISCUSSION}

Technology-wise TechnologyUtilization

\section{Pattern of the Respondents on Cassava cultivation}

Technology Utilization Pattern varies from individual to individual and practice to practice. The results of the study are given in Table 1.

\section{Regarding crop improvement} technologies, 100 per cent of the respondents adopted the recommended suitable varieties, The suitability of the varieties for different soils and increase in yield were the criteria for the selection.

As regards to crop production technologies, 84.16 per cent of the respondents adopted the recommended FYM application. Sett selection was followed by 80.83 per cent of the respondents and spacing of crops by 80 per cent of the respondents.

Table 1.

Distribution of Respondents according to their Technology wise Technology Utilization Pattern

\begin{tabular}{|c|c|c|c|}
\hline \multirow{2}{*}{ SI.No. } & \multirow{2}{*}{ Particulars } & \multicolumn{2}{|c|}{ Technology utilization pattern } \\
\hline & & Number * & Percentage \\
\hline \multicolumn{4}{|c|}{ Crop Improvement Technology } \\
\hline 1. & $\begin{array}{l}\text { Varieties H226,Kungumarose, YTP- } \\
\text { 1, Thailand white, Thailand black, } \\
\text { MUD -1, Burma, Sree Athulya, Sree } \\
\text { apoorva,CO-1, CO-2, CO-3, CO(TP) } \\
\text { 4, CO(TP) } 5 \text {. }\end{array}$ & 120 & 100.00 \\
\hline \multicolumn{4}{|c|}{ Crop Production Technologies } \\
\hline 2. & $\begin{array}{l}\text { Sett selection Setts of } 15 \mathrm{~cm} \text { long with } \\
8-10 \text { nodes from the middle portion } \\
\text { of the stem }\end{array}$ & 97 & 80.83 \\
\hline 3. & Sett treatment & & \\
\hline
\end{tabular}




\begin{tabular}{|c|c|c|c|}
\hline \multirow{2}{*}{ SI.No. } & \multirow{2}{*}{ Particulars } & \multicolumn{2}{|c|}{ Technology utilization pattern } \\
\hline & & Number* & Percentage \\
\hline a. & $\begin{array}{l}\text { Fungicides : Dipping setts in } \\
\text { dimethoate @ } 2 \mathrm{ml} / \text { litre of water }+ \\
\text { carbendezim } 2 \mathrm{~g} / \mathrm{l} \text { for } 15 \text { minutes } \\
\text { before planting }\end{array}$ & 30 & 25.00 \\
\hline b. & $\begin{array}{l}\text { Biofertilizer : Dipping setts }(30 \mathrm{~g} \\
\text { azospirillum }+30 \mathrm{~g} \text { phospho bacteria } \\
\text { solution } 1 \text { lit. of water for } 15 \text { minutes }\end{array}$ & 14 & 11.67 \\
\hline 4. & Planting method: Ridges and furrows & 87 & 72.50 \\
\hline 5. & Depth of planting: $4-6 \mathrm{~cm}$ & 95 & 79.16 \\
\hline 6. & $\begin{array}{l}\text { Sett rate; } 17,700 \text { setts/ ha or } 14,800 \\
\text { setts/ ha }\end{array}$ & 93 & 77.50 \\
\hline 7. & Spacing; 90 × 90 cm(12,345 setts/ha) & 96 & 80.00 \\
\hline 8. & $\begin{array}{l}\text { Irrigation; Once in } 7-10 \text { days up to } 3^{\text {rd }} \\
\text { month and once in } 20 \text { days from } 4^{\text {th }} \\
\text { month to } 8^{\text {th }} \text { month }\end{array}$ & 88 & 73.33 \\
\hline 9. & $\begin{array}{l}\text { Intercropping: Aggregatum onion, } \\
\text { coriander, black gram, Bengal gram, } \\
\text { Bengal gram, tomato, brinjal. }\end{array}$ & 55 & 45.83 \\
\hline 10. & Manures and fertilizers & & \\
\hline a. & $25 \mathrm{t} / \mathrm{ha}$ & 101 & 84.16 \\
\hline b. & Basal- 30:60:75 kg NPK/ha & 39 & 32.50 \\
\hline c. & Top dressing-30:75 kg NK/ ha & 90 & 75.00 \\
\hline d. & $\begin{array}{l}\text { Neem blended urea-Urea : neem cake } \\
(5: 1)\end{array}$ & 21 & 17.50 \\
\hline 11. & $\begin{array}{l}\text { Micronutrient treatment; } 0.5 \% \\
\mathrm{ZnSO} 4+1 \% \text { FeSO } 4 \text { solutions sprayed } \\
\text { on } 60^{\text {th }}, 75^{\text {th }} \text { and } 90^{\text {th }} \text { day of planting. } \\
\text { drip- } 90: 90: 240 \mathrm{~kg} \text { of NPK/ha @ once } \\
\text { in every three days }\end{array}$ & 38 & 31.67 \\
\hline
\end{tabular}


Technology Utilization Pattern of Cassava Growers on Recommended Cultivation Practices

\begin{tabular}{|c|c|c|c|}
\hline \multirow{2}{*}{ SI.No. } & \multirow{2}{*}{ Particulars } & \multicolumn{2}{|c|}{ Technology utilization pattern } \\
\hline & & Number* & Percentage \\
\hline \multicolumn{4}{|c|}{ Plant Protection technologies } \\
\hline 1. & $\begin{array}{l}\text { White fly(Neem oil } 5 \mathrm{ml} / \text { lit. or methyl } \\
\text { demeton } 35 \mathrm{EC} 2 \mathrm{ml} / \text { lit.) }\end{array}$ & 50 & 41.67 \\
\hline 2. & $\begin{array}{l}\text { Papaya mealy bug(Release of mealy } \\
\text { bug parasitoid(Acerophagus papaya)@ } \\
100 \text { NOs./acre) }\end{array}$ & 99 & 82.5 \\
\hline 3. & $\begin{array}{l}\text { Scales(Dimethoate }(2 \mathrm{ml} / \text { lit.) or } \\
\text { malathion }(2 \mathrm{ml} / / \text { lit. } \\
\text { dementon }(2 \mathrm{ml} / \mathrm{lit} .))\end{array}$ & 22 & 18.33 \\
\hline 4. & $\begin{array}{l}\text { Red spider mite-Wettable sulphur } \\
\text { ( } 2 \mathrm{~g} / \mathrm{lit}) \text { or dicofol }(2.5 \mathrm{ml} / \mathrm{lit} .)\end{array}$ & 14 & 11.67 \\
\hline 5. & $\begin{array}{l}\text { Mosaic- Dimethoate }(2 \mathrm{ml} / \text { lit.) or } \\
\text { methyl dematon ( } 2 \mathrm{ml} / \text { lit.) }\end{array}$ & 59 & 49.17 \\
\hline 6. & $\begin{array}{l}\text { Tuber rot(Copper oxychloride 2.5g/ } \\
\text { lit.) }\end{array}$ & 23 & 19.17 \\
\hline 7. & $\begin{array}{l}\text { Concentric ring leaf spot (or) } \\
\text { phomadisease (Carbendazim 250g or } \\
\text { mancozeb 625g or coc 625g per ha) }\end{array}$ & 41 & 34.17 \\
\hline 8. & $\begin{array}{l}\text { Cercospora leaf spot(Mancozeb @ 2g/ } \\
\text { lit.) }\end{array}$ & 15 & 12.50 \\
\hline 9. & $\begin{array}{l}\text { Herbicide Application(Pendemethylin } \\
\text { @ 1kg a.i/ha) }\end{array}$ & 77 & 64.17 \\
\hline \multicolumn{4}{|c|}{ Harvesting } \\
\hline 1. & $\begin{array}{l}\text { Correct time of harvesting(Harvesting } \\
\text { at correct time by pulling the stem up) }\end{array}$ & 86 & 71.67 \\
\hline
\end{tabular}

(*) Multiple Responses Obtained

In general, it could be concluded that medium level of adoption was followed by the respondents. Medium level of risk orientation and economic motivation might be the contributing factors for the medium level of technology adoption among the cassava growers.

\section{Overall Technology Utilization Pattern of the} Respondents

The cumulative frequency distribution of Technological Utilization Pattern obtained from the analysis is presented in Table 2. 
Table 2.

Distribution of Respondents according to their Overall Technological utilization pattern.

$(n=120)$

\begin{tabular}{|l|l|c|c|}
\hline \multirow{2}{*}{ SI.No. } & \multirow{2}{*}{ Category } & \multicolumn{2}{|c|}{ Technology utilization pattern } \\
\cline { 3 - 4 } & & Number & Percentage \\
\hline 1. & Low & 20 & 16.67 \\
\hline 2. & Medium & 69 & 57.50 \\
\hline 3. & High & 31 & 25.83 \\
\hline Total & 120 & 100.00 \\
\hline
\end{tabular}

It could be observed from the table that the majority of the respondents(57.50\%) had medium level of technology utilization pattern in cassava cultivation, followed by high level (25.83\%) and low level (16.67\%) of technology utilization pattern.

The medium to high level of technology utilization pattern of the respondents might be due to their high level of knowledge on recommended practices, medium level of risk orientation and medium level of economic motivation. Further, the agricultural scientists from Tapioca and Castor Research Station, Yethapur, Tamil Nadu in the study area might have also played an important role in the dissemination of technologies on cassava cultivation.

However low knowledge on biofertilizer application and plant protection measures for certain pests and diseases would have contributed for the low level of technology utilization.

Among the 120 cassava growers, even though high number of farmers were aware of the technologies like crop improvement, crop protection, crop production and harvesting they were not adopting some of the technologies due to the fear of economic loss since cassava is a long duration crop and it affects income. Hence, intensive efforts like organizing training cum demonstrations, distributing extension literature and arranging exhibitions are to be undertaken by the extension personnel of Department of horticulture to improve the technology utilization pattern of cassava growers.

\section{REFERENCES}

Howeler, R., Lutaladio, N., \& Thomas, G. (2013). Save and grow: Cassava. A guide to sustainable production intensification: FAO. 